\title{
TOLERANCE AS AN AXIOLOGICAL PRINCIPLE OF NONVIOLENT ACTION IN TRANSITIONAL DEMOCRACIES
}

\section{Andrushchenko T. V., Melnyk V. V.}

\section{INTRODUCTION}

Overcoming a collision of values provides a task of forming a single world-view platform from which various (even opposite) values are perceived as those having a right to exist and that need a proper attitude. This platform is tolerance. Forming it is perhaps the uppermost task for bringing civilizations closer together and establishing relations, not confrontation, between them. In this regard, it is necessary to clarify the deep imperatives of the principle of tolerance and follow the progressive trajectory of the acquisition of the concepts of operational and analytical senses. Therefore, the purpose of this article is to identify the ethical grounds for behavior to which tolerance binds and justify the foundations of a nonviolent worldview as a methodological foundation for truly democratic forms of cohabitation. In a practical and transformative sense, the article aims to provide political dialogue subjects with clear guidance on which directions to follow in the process of communicative exchange and the manifestations of ongoing interactivity.

The concept of tolerance has many meanings and is used in various fields of knowledge: philosophy, theology, medicine, psychology, sociology, political science and others. The etymology of the term "tolerance" is associated with the Latin verb "tolero", which means to "bear", "hold", "endure". This verb was used when it was necessary to literally carry or hold something. It implied that in order to hold and carry a thing, one must make an effort, suffer and endure.

The emergence of the very concept of tolerance dates back to the sixteenth century, the time of split in the Christian church and further opposition between the sides. During this period, it had a more limited meaning and was used to refer to tolerance of other religious beliefs. Later, the context of application of this concept considerably expanded: it began to denote tolerance to other 
political and ideological views, cultural and ethnic values, norms, lifestyles. However, despite the widespread use of the term "tolerance" in the modern world, the definition of this concept is still a pressing scientific problem.

\section{The Interpretation of the Concept of "tolerance" in Modern Scientific Research}

First of all, it is worth mentioning that the literal translation of the Latin word "tolerantia" - "patience" - does not fully convey the meaning of the concept of tolerance, weakening it. According to M. Mchedlov, tolerance traditionally means only a willingness to condescend to another's opinion and even expresses a kind of advantage over other - tolerated - beliefs, whereas tolerance does not imply condescension, but also benevolence, willingness to engage in respectful dialogue and cooperation ${ }^{1}$.

P. Hrechko also suggests to differentiate the concepts of "patience" and "tolerance". To be patient means to unwittingly accept the existence of someone or something. At the same time one is usually patient to something that is unpleasant, that causes suffering and loathing. Tolerance is the recognition and reverence of other views, beliefs, traditions, styles and practices of life without internal agreement with them. Tolerance may also be limited by an external response (restraint, for example); it also requires a "deeper plan" (accepting the value of difference). In evolutionary terms, patience slowly but steadily rises to the level of tolerance and, in essence, becomes it.

Hence, according to P. Hrechko, the first in the semantics of tolerance is the layer of religious tolerance. It absorbs the sheer discomfort of being in the presence of something else, a tense ban on negative emotions, forced acceptance of common sense, involuntary indulgence, etc. However, with the pass of time, the colors of history have also changed, and there emerged a new semantic layer in the problem of tolerance. It brought to the fore the awareness of the value of cultural diversity, recognition of a person's inalienable rights and freedoms, motivation of initiatives and alternatives and respectful attitude to others ${ }^{2}$.

\footnotetext{
${ }^{1}$ Толерантность / общ. ред. М. П. Мчедлова. Москва : Республика, 2004. С. 12.

${ }^{2}$ Гречко П. О границах толерантности. Свободная мыслль - XXI. 2005. № 10. C. 174-175.
} 
Based on diversity in the meanings of the term "tolerance", E. Shlykova distinguishes two primary types of tolerance related to the peculiarities of forming this trait in the process of personality development. The first of these is based on perceptions of tolerance as the ability to tolerate, to put up with something that causes misunderstanding, rejection, protest. Tolerance-patience implies the presence of internal tension as a result of self-violence, prohibition of negative behaviors. Tolerance of this type conceals various forms of violence, aggression and ignoring the subjective characteristics of another. The second type, tolerance-acceptance, is broader than simple tolerance: it is the conscious acceptance of differences, peculiarities and diversity of the surrounding world and recognition of universal human rights and freedoms ${ }^{3}$.

It is this modern interpretation of tolerance that underlies international documents, namely, the Declaration of Principles on Tolerance, adopted by UNESCO on 16 November $1995^{4}$. According to it, tolerance means respect, acceptance and a proper understanding of the rich diversity of cultures of our world, our forms of selfexpression and ways of manifesting human individuality. Tolerance is harmony in diversity. It is not only a moral obligation but also a political and legal need. It is a virtue that makes peace possible and helps replace the culture of war with the culture of peace.

At the same time, tolerance implies an active attitude to the world because, according to the Declaration of Principles on Tolerance, it is not concession, condescension or indulgence but, first and foremost, an active attitude formed on the basis of the recognition of universal human rights and fundamental freedoms. It is a duty to promote human rights, pluralism, democracy and the rule of law. Tolerance does not mean tolerating social injustice, abandoning one's or giving in to someone else's beliefs. This means that everyone is free to abide by their beliefs and recognizes the same right of others.

${ }^{3}$ Шлыкова Е. В. Толерантность и миграционные процессы в контексте социологии риска: автореф. дисс. к.соц.н.: 22.00.04. Москва, 2008. С. 13.

4 Декларація принципів толерантності затверджена резолюцією 5.61 генеральній конференції ЮНЕСКО від 16 листопада 1995 p. URL: http://zakon.rada.gov.ua/cgi-bin/laws/main.cgi?nreg=995_503 (дата звернення: 30.09.2019). 
Therefore, tolerance should not be considered indifference or passivity in any way. A special emphasis on activity as a significant feature of tolerance makes I. Levchenko, according to whom tolerance acts as a specific type of individual and social attitude to social and cultural differences, the attribute of which is an active (as opposed to indifferent) position of perception the diversity of the social world ${ }^{5}$.

Having analyzed the basic meanings of the verb to "tolerate", V. Khanstantynov sees the general basis of tolerance in the conscious manifestation of volitional efforts on the part of a person in determining his or her certain attitude to negative stimuli and influences from the outside, which is manifested in conscious reconciliation (though, to an extent) ${ }^{6}$.

At the same time, it cannot yet be argued that the concept of tolerance has a clear interpretation, which would be supported by most researchers. On the contrary, this question remains open because of the multidimensionality, complexity, even paradox, of the phenomenon of tolerance.

At the same time, it is yet too early to state that the concept of tolerance has a clear interpretation supported by most researchers. On the contrary, this question is still open owing to the multidimensionality, complexity and even anomaly of the phenomenon of tolerance.

V. Lektorskyi, emphasizing the complexity and multidimensionality of the phenomenon of tolerance, notes that the idea of tolerance, seemingly very simple, is not actually so since it comes from certain preconditions and entails a chain of consequences. The most important thing is that this seemingly rather partial but quite important problem turned out to be connected with a number of fundamental philosophical questions concerning the understanding of an individual, their identity, possibilities and limits of cognition and understanding ${ }^{7}$.

5 Левченко И. Н. Ценности толерантности и терпимости принимающего сообщества в условиях миграционной подвижности населения юга России: автореф. дис. ... канд. социолог. наук. Ростов на Дону, 2006. С. 17.

6 Ханстантинов В. О. Толерантність як риса світоглядної позиції особистості. Наукові праці. Серія «Політологія» 2008. Т. 79. Вип. 66. С. 29.

7 Лекторский В. А. Эпистемология классическая и неклассическая. Москва: Эдиториал УРСС, 2001. С. 21. 
In general, V. Lektorskyi differentiates four possible ways ("ideal types") for understanding tolerance:

- tolerance as an indifference that assumes the existence of thoughts whose truth can never be proved (religious views, specific values of different cultures, particular ethnic beliefs and beliefs);

- tolerance as an inability to understand limited by respect for others, who one can neither understand and nor interact with;

- tolerance as a indulgence that implies an individual sees his or her own culture privileged. They see other cultures as weaker, and hence tolerance towards them combines with some disdain and contempt;

- tolerance as an extension of one's own experience and critical dialogue that combines respect for positions of others aiming at mutual exchange of positions as a result of a critical dialogue . $^{8}$

According to M. Walzer, tolerance as an attitude or mood, includes such a selection of opportunities. The first of these, rooted in the practice of religious tolerance of the sixteenth and seventeenth centuries, is nothing more than an alienated and submissive attitude to differences in the name of peacekeeping. The second possible attitude is the position of passivity, relaxation and gracious indifference to differences: "Let all flowers bloom." The third one stems from a kind of moral stoicism - the fundamental recognition that "others" have rights, even if they use those rights in a hostile way. The fourth one expresses openness to others, curiosity, perhaps even respect, the desire to listen and learn. And lastly, the enthusiastic acceptance of differences, the aesthetic approval, in which differences are perceived as a cultural hypostasis of the vastness and diversity of God's creations or nature; or else it is a functional endorsement, in which differences are seen as an indispensable condition for the flourishing of humankind, which gives any man and any woman the full freedom of choice, because freedom of choice constitutes the meaning of their autonomy ${ }^{9}$.

E. Kazachynskyi distinguishes the following dimensions of the phenomenon of tolerance. First, it is a manifestation of the specific natural psychological contents of the personality, belonging to the so-

8 Лекторский В. А. Эпистемология классическая и неклассическая. Москва: Эдиториал УРСС, 2001. С. 23-31.

9 Уолцер М. О терпимости. Москва: Идея-Пресс, Дом интеллектуальной книги, 2000. С. 26-27. 
called affective type with developed empathy, capacity for empathy, compassion, positive openness to people, altruistic disposition, optimistic worldview.

Secondly, tolerance is acquired under the influence of the outside or through self-education by the ability of the individual to consciously exhibit patience towards actions, thoughts and evaluations with which he or she disagrees. Such tolerance is first of all the result of rational understanding and justification of the need, importance and usefulness of tolerant consciousness and behavior.

Thirdly, tolerance as one of the highest values of humanism is objectified in the norms and values of culture, law and civilized way of life. It functions as a special moral and psychological background under which various human relationships are practiced daily.

Fourth, tolerance is a political ideal that inspires progressively thinking people to work hard to improve society itself, to give a clearer orientation to their difficult efforts, especially in the context of the domination of traditionally patriarchal, authoritarian, conservative, and conservative traditions in social life and public consciousness ${ }^{10}$.

In today's multicultural society, tolerance is acting as a means of regulating interaction between diverse social groups. And on a global scale, tolerance is seen as the normative basis of international relations to ensure the peaceful coexistence of different nations and cultures while preserving their identity. All this gives us a reason to talk about the regulatory function of tolerance.

As P. Saukh and Y. Saukh point out, tolerance is an important moral and practical guide to the principles of integrating cultural and historical experience into a single system of values. It is a mechanism of behavior of social entities (parties, ethnic groups, churches, etc.) which, in the process of their mutual respect, conscious rejection of violence, implies humiliation of each other's dignity. It is, therefore, an important condition for social regulation of human relations, an important manifestation of the moral and humanistic nature of the subjects of relationships, a certain ingredient without which a normal

10 Казачинський Є.Г. Проблеми формування толерантності під час вивчення курсу історії. Наукові прац̧і. Серія «Політологія». 2008. Т. 79. Вип. 66. C. 57. 
human being, as well as a stable life of society, is impossible or possible in a destructive form ${ }^{11}$.

I. Kushnirenko points out that tolerance is objectively required as a binding regulatory tool, as a multifaceted "organizing force" in the development of society and social consciousness which allows it to be considered as a structural component in the organization of society. Therefore, it should be true to understand that tolerant attitude towards one another, solidarity, dialogue and understanding should become the norm of behavior and actions of all, without exception, by people, political parties, public organizations and movements, states and their institutions ${ }^{12}$.

As part of sociocultural analysis, I. Levchenko views tolerance as a semantic value that is formed in a particular sociocultural environment which attributes to her the status of a regulator of social interaction, one of the criteria for evaluating events, actions, ideas and thoughts. In addition, tolerance is defined in the categories of social norms and attitudes that capture the level of sufficiently specific behavioral prescriptions. In general, tolerance as a sociocultural value and norm should regulate interpersonal and intergroup relations in society ${ }^{13}$.

Considering tolerance as a semantic category governing relations between people, P. Davydova considers that in the contemporary socio-cultural space it is understood as a certain established mechanism that centralizes or mitigates numerous contradictions and differences as well as one of the possible ways overcoming various forms of aggression, conflict, tension and extremism ${ }^{14}$.

O. Stohova considers the principle of tolerance as one of the basic moral regulators of human relations. In her opinion, tolerance has the nature of a moral ideal, which is formed as a result of the historical selection of rules of coexistence, norms of behavior and passes to the

${ }^{11}$ Саух П., Саух Ю. Толерантність у контексті сучасних духовно-ціннісних трансформацій. Історія. Філософія. Релігієзнавство. 2008. № 2. С. 4.

12 Кушніренко І. Ю. Міжнаціональна толерантність в політичному процесі сучасної України: автореф. дис. канд. політ. наук: 23.00.02. Одеса, 2008. С. 8.

13 Левченко И. Н. Ценности толерантности и терпимости принимающего сообщества в условиях миграционной подвижности населения юга России: автореф. дис. канд. социолог. наук. Ростов на Дону, 2006. С. 16-17.

14 Давидова М. В. Права людини та громадянина в сучасних демократіях : автореф. дис. на здобуття наук. ступеня канд. політ. наук : спец. 23.00.02. Миколаїв, 2004. С. 5. 
level of worldly positions in the consciousness of the subjects of interaction $^{15}$.

Based on a synergistic approach, V. Lohvynchuk considers tolerance as a necessary precondition for the optimum action of mechanisms of self-regulation and development of society in the conditions of globalization, under which its stability increases, the transition of the social system to an entropy state is inhibited ${ }^{16}$.

Of particular importance is the regulatory function of tolerance for the prevention and resolution of conflicts. For example, E. Bystrytskyi considers tolerance as a mode of action (behavior) capable of keeping conflicting parties from actual violence, that is, as a conscious creation of a situation of tolerance. The situation of tolerance is a situation of creating conditions, including ideological and threatening means, rational-critical, argumentative discourse aimed at reaching a mutually agreeable agreement, a treaty that would have valid regulatory restraints. The primary precondition for a situation of tolerance is the ability to negotiate. To agree is to replace the possibility of a real force collision with language, communication and outreach. And these actions should be based on the principles of "communicative ethics"17.

O. Zarivna also emphasizes the important role of tolerance in ensuring peace and harmony. In her view, tolerance, which means respect, acceptance and a proper understanding of all the diversity of cultures, forms of self-expression and the manifestation of human personality, makes it possible to achieve peace. It encompasses values, attitudes and behaviors that reflect and inspire social interaction and cooperation based on the principles of freedom, justice and solidarity, which deny violence and address conflicts by addressing their causes, in order to solve problems through dialogue and negotiations,

15 Стогова О. В. Людський вимір етнонаціональної політики та його реалізація в Україні : автореф. дис... канд. політ. наук: 23.00.02. Харків, 2005. C. 13 .

16 Логвинчук В. В. Толерантність як ціннісна детермінанта політичної культури: автореф. дис...канд. політ. наук: 23.00.03. Київ, 2007. С. 18.

17 Бистрицький С. Конфлікт культур і філософія толерантності. Демони миру та боги війни. Соціальні конфлікти посткомуністичної доби. Київ: Політична думка, 1997. С. 149. 
guaranteeing the opportunity to fully enjoy all the rights and means to participate in the development of their society ${ }^{18}$.

Exploring the role of tolerance in regulating relations in a modern multicultural society, S. Drozhzhyna highlights the following traits that enhance the effectiveness of citizens and promote peaceful resolution of conflicts: a sense of unity in diversity, search for compromises, civic sentiment, patriotism, patriotic opinions of others, respect for the rights of others, personal responsibility (to the family, members of the community, the state), self-discipline (voluntary compliance with laws and rules), broad outlook and critica thinking ${ }^{19}$.

At the personal level, the regulatory function of tolerance acts as self-regulation. According to P. Polyakov, tolerance promotes selfregulation of the person through a conscious attitude to norms, assessments and self-esteem. It is an internal position of identification and isolation that allows to maintain stability, peace, balance and confidence. It is a position that contains respect for the other and for oneself, the integrity of one's self and connection with the world ${ }^{20}$.

According to N. Khanstantinov, its ultimate qualitative design in the worldview position is acquired by tolerance in the real ability of the individual to self-regulate in verbal and non-verbal behavior in the conditions of its interaction with the social environment, especially in view of his multicultural composition. The social value of tolerance as a trait of ideological position is shown in the following.

First, formed tolerance allows one to assert themselves as a being that is emotionally sensitive, attuned to the humanistic values of freedom, democracy and human rights and to declare themselves as a carrier of qualities of high civility and culture, as a person who is able to possess his own emotional states and experiences.

18 Зарівна О. Т. Мова як чинник формування толерантності студентської молоді в глобалізованому суспільстві: автореф. дис. канд. пед. наук: 13.00.01. Київ, 2008. С. 10-11.

19 Дрожжина С. В. Толерантність як дієвий чинник демократизації сучасного українського соціуму. Мультиверсум. Філософський альманах. 2006. № 55. URL: www.filosof.com.ua/Jornel/M_55/Drozhzhina.htm (дата звернення: 30.09.2019).

20 Поляков П. М. Проблема толерантності в контексті формування іï світоглядних джерел. Гілея (науковий вісник). 2010. № 30. URL: http:// www.nbuv.gov.ua/portal/Soc_Gum/Gileya/2010_30/Gileya30/F1_doc.pdf (дата звернення: 30.09.2019). 
Secondly, the formed tolerance helps to define a person as a communicable being, which in turn allows them to more successfully, more efficiently carry out various social interactions by character, to realize a wider range of social roles and functions.

Thirdly, the formed tolerance orientates the activity on the improvement of the society itself, its political system, in particular, in the direction of strengthening the foundations of the rule of law, the establishment of the rule of law, the institution of human rights.

Fourth, the tolerance of each individual is the key to the formation of a tolerant atmosphere of society in general, in which the diversity of ideas, cultures, languages, types of mentality, traditions, lifestyles, models of life presentations of "I-concept", etc., is not perceived as a threat to the unity of society, and an indispensable prerequisite for enriching and strengthening public relations within it.

Fifth, a culture of tolerance can act as a kind of social stabilizer, slowing down the processes of internal contradictions in society while minimizing the severity and intensity of the negative consequences of conflicts of interest ${ }^{21}$.

Therefore, tolerance in modern conditions is regarded as one of the main factors of order, harmony and peace in a multicultural social space. Hence, there is a need for deliberate upbringing and selfcultivation of tolerance.

In a transforming heterogeneous society, tolerance is an essential basis for achieving and maintaining trust, socio-political coherence, and openness to polylogy. The clear contradictions in the social, linguistic, ethnic, economic, religious spheres of social life are particularly relevant to this issue for contemporary Ukraine. Particular attention should be paid to the value, moral and ethical aspects of the interaction of different political actors, the degree of compromise of political struggle, and the problems of mutual trust of the public in the context of transitional political dynamics. Therefore, harmonization of diverse interests in Ukrainian society, adherence to the course of civilized, democratic development is not least dependent on the nature and dynamics of the political dimension of tolerance.

In a broad sense, V. Khanstantynov notes that political tolerance/ intolerance reflects the attitude of individuals to each other in different

21 Ханстантинов В. О. Толерантність як риса світоглядної позиції особистості. Наукові праці. Серія «Політологія» 2008. Т. 79. Вип. 66. С. 31-32. 
spheres of public relations if the peculiarities of their course and the consequences of their interactions have a politically significant impact on the life of the groups of people involved and are assessed by them in the context the relationship "state-society", "authority-citizen" 22 Political tolerance is especially important in the processes of democratization and humanization of the political life of the society, consolidation of the political system. A democratic type of political culture is unthinkable without a high level of tolerance. Political tolerance as a type of individual and social attitude to social and cultural differences, as tolerance of others' thoughts, beliefs and behaviors, can be considered one of the fundamental signs of civility and a high level of the civic culture.

\section{Formation and Development of Political Tolerance in Modern Ukraine}

In today's Ukraine, the problem of becoming politically tolerant implies a humanistic thrust of socio-political transformation, which is an important guarantor of the establishment of democratic values in society. Exploring the problems of national understanding in Ukraine, Ukrainian political scientist V. Yakushyk emphasizes the diversity of the Ukrainian society as a real fact, the rootedness of diverse interests in the historical-civilizational and political process of Ukraine, the natural dissimilarity of ideas about the civil agreement and ways of achieving $\mathrm{it}^{23}$. Recognition of the multiplicity of political interests and the simultaneous pursuit of public understanding are the two interdependent and necessary components of political tolerance in democratization.

In today's world, where there is no civilized and humane alternative to counteracting political conflicts other than tolerance, the question of recognition, independence, autonomy of the individual, their personal responsibility for their beliefs and actions, unacceptability of forceful imposition remains open to the Ukrainian society. The political dimension of such tolerance is possible through

22 Ханстантинов В. О. Політичний вимір толерантності: ідеї та проблеми: монографія. Миколаїв: Вид-во ЧДУ імені Петра Могили, 2011. С. 253.

Якушик В. Концептуальні та інституційні аспекти проблеми національного порозуміння в Україні. Сучасна українська політика. Політики $i$ політологи про неї. Київ, 2007. Вип. 10. С. 235. 
the democratic progress and development of civil society, the source of which is the sovereign people. The resources of the Ukrainian people to self-organization and state formation have been tested by numerous protests, disobedience, revolutions. In these events, Ukrainians demonstrated their democratic, tolerant potential, which can be a sound basis for legitimate government and protection of the national interests of the state.

Modern sociological researches show the benefit of maintaining peaceful traditions of social and political activity among young civic activists in Ukraine. Hence, according to the results of an expert poll by the Ilko Kucheriv Democratic Initiatives Foundation "20th Anniversary of the Student Revolution in Granite: Are Today's Youth Ready for Protest Actions?" Most of the civic activists surveyed demanded collective distribution and leaflet distribution, while preventing the use of forceful methods of political struggle ${ }^{24}$.

Along with such historical, mental, traditional foundations of political tolerance in modern Ukraine, one should also dwell on the particular problems of its assertion in the real political life of society. As M. Ryabchuk rightly points out, today's Ukraine is in many ways a premodern country - both in view of the feudal-paternalistic economy and in view of the pre-national "local" identity of many residents and a number of other, actually medieval, traits. Such society is not civic; "tolerance of otherness" in it should not be confused with tolerance. If "tolerance" is a trait forced and temporary, the scientist believes, then it is at the same time a trait permanent and deeply rooted in the whole system of views and values of man. Liberal democracy is based on tolerance; the liberal authoritarianism that we now have in Ukraine is on the forced (and therefore seemingly) tolerated power of certain democratic institutions and procedures ${ }^{25}$. Therefore, in today's Ukraine, intolerance is manifested above all in the struggle of different clans

24 20-річчя Студентської революції на граніті: чи готова сьогоднішня молодь до акцій протесту? (23-27 вересня 2010 р.) Фонд «Демократичні ініціативи» ім. Ілька Кучеріва : Веб-сайт. URL: http://dif.org.ua/ua/press/berkgoljk (дата звернення: 30.09.2019).

25 Рябчук М. Від Малоросії до України: парадокси запізнілого націєтворення. Київ: Критика, 2000. С. 37-38. 
for political power and its social, political, economic and other prerogatives.

The problems of forming political tolerance in the Ukrainian society are exacerbated by transitional political dynamics. We agree with O. Babkina's position that the existing dimensions of civic culture are a sense of personal political importance, i.e., real involvement in political events, the ability to influence them in one way or another; tolerance of others' views and positions, political tolerance, support of individual rights and freedoms, trust in existing political institutions, and others are not yet widespread in Ukrainian society. Numerous sociological surveys conducted in recent decades confirm the internal contradictions in the mass consciousness of postSoviet Ukraine. The bifurcation of the mass consciousness in Ukraine has been empirically repeatedly recorded. People express mutually exclusive opinions, support values and orientations that contradict each other ${ }^{26}$. Therefore, in the context of incompleteness of democratic political processes and uncertainty of the socio-political model of development, pluralism and democracy can lead to a decrease in the control of society, or even to the establishment of undemocratic forms of government.

A specific feature of the modern Ukrainian society is the combination of various types of social connections, cultures and subcultures, characteristic of both closed and open societies, individualistic and collectivist, agrarian and industrial, dogmatic and critical, traditional and modernist. At the same time, none of them can claim absolute truth. That is why, as V. Kremen and V. Tkachenko state, the legitimacy of political power in Ukraine can only be pluralistic, and the political-legitimation process must acquire the characteristics of humanism, spiritual validity ${ }^{27}$. Positively evaluated pluralism and tolerance, respectful attitude to the achievements of past epochs, experience of different societies of

26 Бабкіна О. В. Особливості політичної трансформації на постсоціалістичному просторі: підходи до осмислення. Трансформація політичних систем на постсоціалістичному просторі: матеріали міжнародної науково-теоретичної конференції, 8-9 лютого 2006 р. Київ: Вид-во НПУ ім. М. П. Драгоманова, 2006. С. 8-16.

27 Кремень В., Ткаченко В. Україна: шлях до себе: Проблеми суспільної трансформації : навч. посібн. для студентів вищих навч. закл. Київ : Вища школа, 1999. С. 383. 
significance of all cultural archetypes, recognition of the self-worth and equality of different styles of political thinking, overcoming the borders between elitist and mass political cultures, political character. Political reforms can only be successfully implemented by such legitimate and voluntary authority, which follows from the unity of political traditions, morals, and spiritual precepts. Only such legitimacy becomes the measure of political agreement of political agreement between participants of political-power relations. Such a power is able to coordinate the values of different groups of people regarding the goals and means of transformation and not to allow social and cultural, ideological contradictions to grow.

It should be noted that since the declaration of the independence of Ukraine, the national politics has completed its demarcation with the former policies and practices of a totalitarian society, evolving towards democracy and freedom, gradually affirming new philosophical and ideological priorities that underpin the values of democracy and the values of democracy, the values of democracy human-centrism, tolerance and multicultural communication, the revival of national culture, the establishment of independent statehood, the establishment of equal and fair relations and cooperation with states, cultures and peoples of the world.

In the context of cultural pluralism and the dialogue of cultures, tolerance is seen as an important cultural value of civilization, which lays the foundation for solving the problem of intercultural and interethnic interaction without the use of force and economic pressure, and preserves peace and tranquility.

$\mathrm{H}$. Kovadlo views tolerance as a compensation for dissent in a world where compromise is unachievable. After all, tolerance values diversity, non-identity, difference - individual, social, cultural, etc. Today, the modern world needs this restraint in relation to the other, to the differences and "inequalities" that exist in the world at large. The upbringing of this virtue and the affirmation of an ethos of tolerance (at least at the level of human relations) becomes an urgent need for a modern, sufficiently pluralised and riddled with contradiction in the world. The advocate of tolerance proceeds from the belief that moral ambivalence is a fundamentally insurmountable basis for human existence, it does not exclude itself from the evil in which it lives, and does not depart from the good in whose name it lives. This is not 
about eliminating violence, conflict or the like. Conflict, like evil in general, is rooted in historical and psychological experience, in human ontology itself. It can be a qualitative change in the vector of conscious human effort - individual, collective, socially organized. These efforts are aimed at breaking out of the "enchanted" circle of discord, hatred, intolerance, etc. so that the previous evil does not become an absolute barrier to future cooperation ${ }^{28}$.

V. Sokolov relates the acute nature of the problem of the formation of tolerance values in the modern world to a number of reasons, among which is a sharp stratification of the world civilization on economic, social, moral and ethical, other grounds and the related increase of intolerance, religious extremism; aggravation of ethnic relations caused by local wars; problems of refugees, change of moral paradigms, etc. ${ }^{29}$.

V. Lektoskyi sees dramatism of the current situation in that on the one hand, intolerance in the modern world is not diminishing, but on the other, it is quite clear that without the cultivation of tolerance it is more than likely the mutual destruction of different civilizations, cultures, social and ethnic groups. It is possible to avoid confrontation of civilizations, the possibility of which is absolutely real today, only on the way of critical dialogue of cultures, on the way of rejection of individual and cultural "self-centrism", on the way of finding compromises and agreements, on the way of self-change, on the way of joint solution of the difficulties encountered. in its development modern civilization $^{30}$.

Tolerance as a cultural value of civilization becomes especially relevant in the conditions of globalization processes. As A. Halkin and Y. Krasin point out, turning the world into a whole society, globalization is changing the measure of "us" and "them". If previously unclear and unacceptable existed somewhere far away, without affecting us directly, today, thanks to the latest communication technologies, it is close, directly invading our lives,

${ }^{28}$ Ковадло Г. П. До питання про цінність толерантності у сучасному світі. Мультиверсум. Філософський альманах. 2005. № 51. URL: www.filosof.com.ua/ Jornel/M_51/Kovadlo.htm (дата звернення: 30.09.2019)

29 Соколов В. М. Толерантность: состояние и тенденции. Социологические исследования. 2003. № 8. С. 55.

30 Лекторский В. А. Эпистемология классическая и неклассическая. Москва: Эдиториал УРСС, 2001. С. 31. 
and requires immediate reaction. "Us" and "them" have been pressed into global information and financial flows. The high density of the network of global international, intergroup and interpersonal connections does not allow to deviate from contacts, remain indifferent or neutral. In such close interaction, the risk of rejection, hostility and direct encounters increases dramatically. Only the culture and skills of high tolerance can remove this danger ${ }^{31}$.

M. Khomyakov considers the contradiction between universalism on the one hand and the multiplicity of original cultures on the other the central problem of modern civilization. This contradiction is not only static - in oppositions such as "universal values - distinctive cultures", but more importantly, dynamically - in the confrontation of two tendencies within multiculturalism. Namely, the globalization aspirations that are oriented towards unification and unity counteract the desire of national cultures to preserve their identity. This, according to M. Khomyakov, explains the special relevance and significance of the problem of tolerance in the context of modern civilization. In fact, tolerance can be a normative mediator, a mediator between national culture on the one hand, and global civilization on the other ${ }^{32}$.

Until recently, understanding of tolerance was based on the values of Western civilization. According to A. Pertsev, this is a tolerance whose principles were developed in the space of Western culture - the culture of industrial-market civilization; this is the tolerance attained in relations between people who embrace European values, spread throughout the New Age by the efforts of education, and which have now become the basis of "common human values" as the basis for documents of the international community; this tolerance, which is secured and justified by purely rational means, is achieved on a reasonable basis, and "reason" is again interpreted in the tradition of European culture $^{33}$.

31 Галкин А. А., Красин Ю. А. Культура толерантности перед вызовами глобализации. Сочииологические исследования. 2003. № 8. С. 64.

32 Хомяков М. Б. Толерантность - парадоксальная ценность. Журнал соџиологии и соџииальной антропологии. 2003. Т. VI. № 4. С. 98-112.

33 Перцев А. В. Ментальная толерантность. Толерантность. Вестник Уральского межрегионального института общественных отношений. 2002. № 1. URL.: http://www.eunnet.net/vestimion/01_02/004.html (дата звернення: 30.09.2019). 
V. Lohvinchuk also points out that usually the introduction of tolerance within a particular distinctive culture is a dilemma - whether adaptation of universal values, including tolerance, to each individual culture is possible, or even a minimal adaptation of universal values. Those cultures and religions in which the fundamental values are contrary to the universal and a priori exclude the functioning of tolerance, are forced to change and lose the features of identity that are contrary to peaceful coexistence with other cultures. And this is a requirement of the modern world. Awareness of the priority value of one's own culture should not mean disrespect for other people's beliefs and differences. Original cultures are forced to combine awareness of the priority value of one's own identity with a respectful attitude towards the differences of representatives of other cultures. Otherwise they will not be able to develop in the global world. And that is a serious challenge. Tolerance implies the existence of diversity and "otherness", but only if the latter does not rule out the peaceful coexistence of the sets of "othernesses"

\section{CONCLUSIONS}

Therefore, in today's global and multicultural world, tolerance cannot and should not be based on one rationale that excludes all others. In particular, as the authors of the monograph "Sociology of Interethnic Tolerance" point out, it makes no sense to try to promote the development of tolerance in theocratic societies, arguing its need for the principle of individual autonomy, since it is fundamentally contrary to the basic attitudes of these societies. One possible way out of this situation is the pluralism of the bases of tolerance, the ability to use the various resources provided by the history of this idea to promote tolerance in the modern world. This means that, while endorsing human rights principles, one should not forget that tolerance can be fully justified and in many other ways, perhaps, is less stable in the long run but more acceptable today. In the modern world, they meet (and even sometimes collide) completely different in their principles of culture and civilization. Not all of them share the European principle of autonomy of the individual, who has the right to determine his own life and destiny. Therefore, despite the

34 Логвинчук В.В. Толерантність як ціннісна детермінанта політичної культури: автореф. дис. канд. політ. наук: 23.00.03. Київ, 2007. 20 с. С. 3. 
greatest stability of human rights-based theories, all other concepts still hold their value. In a situation of interaction of cultures, civilizations and values that do not exclude contradictions, one cannot seriously count on the domination of the single "most true" theory of tolerance. The pluralism of the modern world requires pluralism on the basis of a tolerant consciousness ${ }^{35}$.

Therefore, in the modern world, tolerance acts as a major outlook for moral and political attitudes towards the convergence of civilizations, which has considerable peacekeeping potential. The realization of this potential requires further dialogue and cooperation between representatives of different cultures and different sciences in order to improve understanding of the idea of tolerance, its fundamental principles, values, conditions of formation, forms and methods of education and implementation of these ideas in life.

\section{SUMMARY}

The essential aspects of the principle of tolerance have been investigated, and the philosophical and ontological origins of the formation of the concept as well as the evolution of its ideological content have been observed. A comparison of the discussion elements of tolerance determination has been made, and some ambivalence in the concept of the phenomenon and the interpretation of a number of terminological characteristics have been ascertained. Particular attention is paid to the axiom of nonviolent forms of political communication in the context of the transition to democracy updated in this context. In particular problems of formations and development of tolerance in modern Ukraine have been broached. Therefore political tolerance has been viewed as a value in the process of democratic transition, first and foremost in the societies such as Ukrainian, which essentially is combination of different types of political cultures and subcultures and has features of open and closed political system, totalitarian and democratic traditions and tendencies simultaneously. The necessity of pluralism of the bases of tolerance has been stressed, especially in societies with different culture, traditions and civilization principles than European, as not all of them share western values, moral autonomy of individual in particular.

35 Социология межэтнической толерантности / отв. ред. Л. М. Дробижева. Москва, Институт социологии РАН, 2003. С. 24-25. 


\section{REFERENCES}

1. 20-річчя Студентської революції на граніті: чи готова сьогоднішня молодь до акцій протесту? (23-27 вересня 2010 р.) Фонд "Демократичні ініціативи» ім. Ілька Кучеріва : Веб-сайт. URL: http://dif.org.ua/ua/press/berkgoljk (дата звернення: 30.09.2019).

2. Бабкіна О.В. Особливості політичної трансформації на постсоціалістичному просторі: підходи до осмислення. Трансформація політичних систем на постсоціалістичному nростор $i$ : матеріали міжнародної науково-теоретичної конференції, 8-9 лютого 2006 р. Київ: Вид-во НПУ ім. М.П.Драгоманова, 2006. C. 8-16.

3. Бистрицький $€$. Конфлікт культур і філософія толерантності. Демони миру та боги війни. Соціальні конфлікти посткомуністичної доби. Київ: Політична думка, 1997. C. 147-168.

4. Галкин А. А., Красин Ю. А. Культура толерантности перед вызовами глобализации. Социологические исследования. 2003. № 8. С. 64-74.

5. Гречко П. О границах толерантности. Свободная мысль XXI. 2005. № 10. С. 173-182.

6. Давидова М.В. Права людини та громадянина в сучасних демократіях : автореф. дис. на здобуття наук. ступеня канд. політ. наук : спец. 23.00.02. Миколаїв, 2004. 16 с.

7. Декларація принципів толерантності затверджена резолюцією 5.61 генеральній конференції ЮНЕСКО від 16 листопада 1995 p. URL: http://zakon.rada.gov.ua/cgi-bin/laws/ main.cgi?nreg=995_503 (дата звернення: 30.09.2019)

8. Дрожжина С.В. Толерантність як дієвий чинник демократизації сучасного українського соціуму. Мультиверсум. Філософський альманах. 2006. № 55. URL: www.filosof.com.ua/ Jornel/M_55/Drozhzhina.htm (дата звернення 30.09.2019).

9. Зарівна О. Т. Мова як чинник формування толерантності студентської молоді в глобалізованому суспільстві: автореф. дис... канд. пед. наук: 13.00.01. Київ, 2008. 20 с.

10.Казачинський Є. Г. Проблеми формування толерантності під час вивчення курсу історії. Наукові праці. Серія «Політологія». 2008. Т. 79. Вип. 66. С. 56-61. 
11.Ковадло Г. П. До питання про цінність толерантності у сучасному світі. Мультиверсум. Філософський альманах. 2005. № 51. URL: www.filosof.com.ua/Jornel/M_51/Kovadlo.htm (дата звернення: 30.09.2019)

12. Кремень В., Ткаченко В. Україна: шлях до себе: Проблеми суспільної трансформації : навч. посібн. для студентів вищих навч. закл. Київ : Вища школа, 1999. 446 с.

13.Кушніренко I. Ю. Міжнаціональна толерантність в політичному процесі сучасної України: автореф. дис... канд. політ. наук: 23.00.02. Одеса, 2008. 17 с.

14. Левченко И. Н. Ценности толерантности и терпимости принимающего сообщества в условиях миграционной подвижности населения юга России: автореф. дис. ... канд. социолог. наук. Ростов на Дону, 2006. 27 с.

15. Лекторский B. А. Эпистемология классическая и неклассическая. Москва: Эдиториал УРСС, 2001. 256 с.

16. Логвинчук В. В. Толерантність як ціннісна детермінанта політичної культури: автореф. дис... канд. політ. наук: 23.00.03. Київ, 2007. 20 с.

17. Перцев А. В. Ментальная толерантность. Толерантность. Вестник Уральского межрегионального института общественных отношений. 2002. № 1. URL: http://www.eunnet.net/ vestimion/01_02/004.html (дата звернення: 30.09.2019)

18. Поляков П. М. Проблема толерантності в контексті формування ії світоглядних джерел. Гілея (науковий вісник). 2010. № 30. URL: http://www.nbuv.gov.ua/portal/Soc_Gum/Gileya/2010_ 30/Gileya30/F1_doc.pdf (дата звернення: 30.09.2019)

19. Рябчук М. Від Малоросії до України: парадокси запізнілого націєтворення. Київ: Критика, 2000. 304 с.

20. Саух П., Саух Ю. Толерантність у контексті сучасних духовно-ціннісних трансформацій. Історія. Філософія. Релігісзнавство. 2008. - № 2. С. 2-7.

21. Соколов В. М. Толерантность: состояние и тенденции. Соииологические исследования. 2003. № 8. С. 54-63.

22. Социология межэтнической толерантности / отв. ред. Л. М. Дробижева. Москва, Институт социологии РАН, 2003. $222 \mathrm{c}$. 
23. Стогова О. В. Людський вимір етнонаціональної політики та його реалізація в Україні : автореф. дис... канд. політ. наук: 23.00.02. Харків, 2005. 16 с.

24.Толерантность / общ. ред. М. П. Мчедлова. Москва : Республика, 2004. 416 с.

25.Уолцер М. О терпимости. Москва: Идея-Пресс, Дом интеллектуальной книги, 2000. 160 с.

26. Ханстантинов В. О. Толерантність як риса світоглядної позиції особистості. Наукові праці. Серія «Політологія» 2008. Т. 79. Вип. 66. С. 27-32.

27. Ханстантинов В.О. Політичний вимір толерантності: ідеї та проблеми: монографія. Миколаїв: Вид-во ЧДУ імені Петра Могили, 2011. 336 с.

28. Хомяков М. Б. Толерантность - парадоксальная ценность. Журнал социологии и социальной антропологии. 2003. T. VI. № 4. C. $98-112$.

29.Шлыкова Е. В. Толерантность и миграционные процессы в контексте социологии риска: автореф. дисс. к.соц.н.: 22.00.04. Москва, 2008. 28 с.

30.Якушик В. Концептуальні та інституційні аспекти проблеми національного порозуміння в Україні. Сучасна українська політика. Політики і політологи про неї. Київ, 2007. Вип. 10. С. 224-239.

Information about the author: Andrushchenko T. V., Doctor of Political Sciences, Professor, Department of Political Psychology and Socio-Legal Technologies, National Pedagogical Dragomanov University 9, Pyrohova str., Kyiv, 01601, Ukraine Melnyk V. V.,

Doctor of Philosophy, Professor, Head of the Department of Pedagogy and Psychology, Gorlivsky Institute of Foreign Languages, Far Eastern State University "Donbass State Pedagogical University" 